\title{
コマツナの硝酸イオン濃度および硝酸還元酵素活性に及ぼす生育温度の影響
}

\author{
壇 和弘 $^{1} \cdot$ 大和陽一 ${ }^{1 *} \cdot$ 今田成雄 ${ }^{2}$ \\ 1 独立行政法人農業・食品産業技術総合研究機構 九州沖縄農業研究センター 839-8503 福岡県久留米市御井町 \\ 2 独立行政法人農業・食品産業技術総合研究機構＼cjkstart野菜茶業研究所 514-2392 三重県津市安濃町草生
}

\section{Effects of Growth Temperature on Nitrate Concentration and Nitrate Reductase Activity in Komatsuna (Brassica rapa L. var. perviridis)}

\author{
Kazuhiro Dan ${ }^{1}$, Yoichi Yamato ${ }^{1 *}$ and Shigeo Imada ${ }^{2}$ \\ ${ }^{1}$ NARO Kyushu Okinawa Agricultural Research Center, Mii-machi, Kurume, Fukuoka 839-8503 \\ ${ }^{2}$ NARO Institute of Vegetable and Tea Science, Ano-cho, Tsu, Mie 514-2392
}

\begin{abstract}
To study the effect of the growth temperature on the nitrate concentration and nitrate reductase (NR) activity in komatsuna (Brassica rapa L. var. perviridis), cv. 'Harumi-komatsuna' and 'Rakuten' plants were hydroponically grown under growth temperatures of $10 / 5,15 / 10,20 / 15,25 / 20,30 / 25$, and $35 / 30^{\circ} \mathrm{C}$, and a 12-hr photoperiod at a PPFD of $300 \mu \mathrm{mol} \cdot \mathrm{m}^{-2} \cdot \mathrm{s}^{-1}$. Generally, the nitrate concentration in 'Rakuten' plants was higher than that in 'Harumi-komatsuna'. As the growth temperature increased, the nitrate concentration increased and NR activity decreased in both cultivars. A negative correlation between NR activity and the nitrate concentration was observed. Under high temperature conditions, the NR activity decreased, and, therefore, the nitrate concentration in komatsuna plants increased.
\end{abstract}

Key Words : cultivar, growth chamber, high temperature, hydroponics, low temperature キーワード : 品種, 人工気象器, 高温, 低温, 養液栽培

\section{緒言}

硝酸イオンを多量に拱取すると，人体に有害な亜硝酸イ オンやニトロソ化合物が生成される危険性があると指摘さ れており (Sohar・Domoki, 1980)，硝酸イオンの摂取量を できるだけ低く抑えることが望ましい，我が国では，硝酸 イオンの $80 \%$ 以上が野菜から摂取されている（孫・米山, 1996)。野菜の多くは, 好硝酸性植物であり, 主な窒素源 として硝酸イオンを吸収するため，植物体内に硝酸イオン を蓄積しやすい。特に葉菜類は，比較的若い茥葉を食用と するため, 硝酸イオンの主要な摂取源となる。 そのため, より安心・安全な農作物を提供するといら観点から, 野菜, 特に葉菜類の硝酸イオン濃度を低減させることが求められ ている.

野菜の硝酸イオン濃度には窒素施用量が大きく影響する ことから, 野菜の硝酸イオン濃度を低下させるためには, 過剰な窒素施用を避けることが重要である。例えば, 作付

2013 年 6 月 21 日 受付. 2013 年 9 月 27 日 受理.

本研究は, 農林水産研究高度化事業「野菜に打汀万硝酸塩蓄積 機構の解明と低減化技術の開発」により実施した.

* Corresponding author. E-mail: yyamato@affrc.go.jp
け前の土䁃の窒素診断施肥（加藤ら，2013）や緩効性窒素 肥料を用いた条施肥（建部ら，1996）など，施肥管理によ る野菜の硝酸イオン低減化について多く報告されている. 一方，硝酸同化は硝酸還元酵素（nitrate reductase; NR）に より左右されているので, 野菜の硝酸イオン濃度を低下さ せるためには，窒素の過剰施用を避けること以外に，NR の活性を高く保つことが有効であると考えられる.

葉菜類の硝酸イオン濃度には季節的な変動があり, 高温 期には低温期よりも高い傾向にある（藤原ら，2005; 加藤 ら，2013; 寄藤ら，2005）。従って，硝酸イオンの蓄積は気 温の影響を受けると考えられるが，気温を厳密に制御した 環境下で生育させた野菜の硝酸イオン濃度やNR 活性につ いては検討されて扔らず，これらに及ぼす生育温度の詳細 な影響は明らかではない，そこで，本研究では，硝酸イ才 ン濃度が高い野菜の一つであるコマッナを制御環境下（人 工気象器）で生育させ，硝酸イオン濃度およびNR活性に 及ぼす生育温度の影響について検討した。

\section{材料および方法}

\section{1. 供試材料の育成}

コマツナ（Brassica rapa L. var. perviridis） 'はるみ小松菜” および “楽天’を供試し，陽光ランプを光源としたグロ一 
スチェンバー（コイトトロン 3HN-35DA 特殊型，小糸製 作所）内で育苗特よび栽培を行った。 セル育苗専用培養土 (プリティーソイルゴールド N-140, N 140, P 1,250, K $140 \mathrm{mg} \cdot \mathrm{L}^{-1}$, 大塚産業）を詰めた 288 穴七ルトレイに播 種し, 気温 $25 / 20^{\circ} \mathrm{C}$ (明期 $/$ 暗期), 12 時間日長, 光合成 有効光量子束密度（PPFD） $300 \mu \mathrm{mol} \cdot \mathrm{m}^{-2} \cdot \mathrm{s}^{-1}$ で育苗した. 播種 10 日後に, 両品種とも本葉 1 枚が展開した苗を養液 栽培装置に移植した。養液栽培では，樹脂製コンテナ $(60 \times 37.5 \times 7.5 \mathrm{~cm})$ を栽培槽とし， $8 \mathrm{~L}$ の培養液（大塚 $\mathrm{A}$ 処方 $1 / 2$ 単位, $\mathrm{NO}_{3}-\mathrm{N} 8.3, \mathrm{NH}_{4}-\mathrm{N} 0.8, \quad \mathrm{P} 2.55, \mathrm{~K} 4.3$ me $\mathrm{L}^{-1}$, 大塚化学) に浮かせた発泡スチロール板 (厚さ $1.5 \mathrm{~cm}$ ) の穴 (直径 $2 \mathrm{~cm}$ ) に, ポリウレタンフォームで苗を固定 した. 栽植様式は, $9 \mathrm{~cm}$ 間隔の正三角形植えとした. エアー ポンプを用いて培養液に連続通気し，3 日ごとに培養液を 更新した.

12 時間日長で明期／暗期の気温をそれぞれ 10/5，15/10， $20 / 15,25 / 20,30 / 25$ 打よび $35 / 30^{\circ} \mathrm{C}$ に制御し， 2 品種同時 に養液栽培を行った. 1 温度処理区当たり 1 品種 28 個体 を栽培し， 2 反復の実験を行った. 培養液の温度制御は行 わなかった。

$10 / 5^{\circ} \mathrm{C}$ 区を除き, 目視により収穫適期（最大葉長 $25 \mathrm{~cm}$ 程度（飛騨，2001））に達したと判断した日に地上部を採 取した。 $10 / 5^{\circ} \mathrm{C}$ 区では, 生育がきわめて緩慢であったため, 養液栽培開始から 45 日後に栽培を打ち切り, 地上部を採 取した。採取は，いずれの区でも，その日の光照射開始 4 時間後に行い，生育の揃った 25 個体について，子葉㧊よ び黄化葉を除去して可食部に調製した。 20 個体の最大葉 長, 葉数, 最大葉の葉色 (SPAD-502, ミノルタにより測定), 新鮮重および乾物重を測定し，そのらち 10 個体を硝酸イ オン濃度の測定に用いた. 硝酸還元酵素（NR）活性の測 定に用いるために，5個体を採取後直ちに液体窒素で涷結 し， $-80^{\circ} \mathrm{C}$ で保存した。

育苗拈よび栽培は，2003 年 4 月 14 日〜 12 月 1 日の間 に行った.

\section{2. 硝酸イオン濃度の測定}

乾燥させた可食部全体を均一になるよらに粉砕した，粉 砕した試料 $100 \mathrm{mg}$ に蒸留水 $30 \mathrm{~mL}$ を加え, 3 時間振とら 抽出した。 濾紙（No. 2, 東洋濾紙）で濾過した後, 抽出

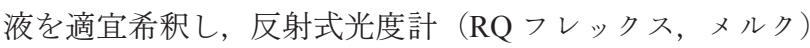
を用いて硝酸イオン濃度を測定した（建部・米山，1995）.

\section{NR 活性の測定}

NR 活性の測定は, Kojimaら（1995）の方法に準じて行っ た. $-80^{\circ} \mathrm{C}$ で保存していた凍結試料に $50 \mu \mathrm{M}$ ロイペプチン, $2 \mathrm{mM}$ 2-メルカプトエタノール，25 mM NaF， $5 \mathrm{mM}$ EDTA および $1 \mathrm{mM}$ フェニルメチルスルホニルフルオリドを含む 50 mM HEPES-KOH 緩衝液（pH 7.7）を試料の 2 倍量加え, 氷冷下の乳鉢中で磨砕抽出した。抽出液を 4 重のガーゼで 濾過した後に $20,000 \times \mathrm{g}$ で 20 分間遠心分離し, 上澄液を粗 酵素液として使用した。 $50 \mu \mathrm{M}$ ロイペプチン， $2 \mathrm{mM} \mathrm{KNO}_{3}$,
$0.25 \mathrm{mM}$ 還元型ニコチンアミドアデニンジヌクレオチド $(\mathrm{NADH}) ， 5 \mathrm{mM} \mathrm{MgCl}_{2}$ （非リン酸化 $\mathrm{NR}$ 活性測定時），また

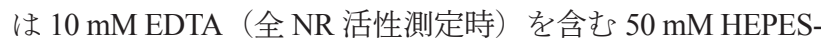
$\mathrm{KOH}$ 緩衝液（pH 7.7） $450 \mu \mathrm{L}$ に粗酵素液 $50 \mu \mathrm{L}$ を加え， $30^{\circ} \mathrm{C}$ で 5 分間反応させた. 反応液に $1 \mathrm{M}$ 酢酸亜鉛を $50 \mu \mathrm{L}$ 加え, 反応を止めた。ささらに, $0.3 \mathrm{mM}$ フェナジンメトスルフェー 卜を $50 \mu \mathrm{L}$ 加えた後, 15 分間放置し， NADH による発色阻 害を防いだ. $800 \times \mathrm{g}$ で 2 分間遠心分離した後の上澄液 $600 \mu \mathrm{L}$ に $1 \%$ スルファニルアミドを含む $1.5 \mathrm{M} \mathrm{HCl}$ と $0.02 \%$ $\mathrm{N}-1$-ナフチルエチレンジアミン塩酸塩水溶液を各 $600 \mu \mathrm{L}$ ずつ加光, 酵素反応により生成した亜硝酸イオンを発色さ せた. 発色 20 分後に，分光光度計を用いて $540 \mathrm{~nm}$ の吸光 度を測定した．ブランクの測定では，粗酵素液を加える前 に，酢酸亜鉛を添加し，同様の操作を行った。

\section{結果および考察}

コマッナ 2 品種 ‘はるみ小松菜”扎よび “楽天”を，最 大葉長を指標として収穫し，その時の最大葉長，葉数，葉 色，ならびに可食部新鮮重および乾物重を測定した（第 1 表)。目視では両品種の生育に大きな差はみられなかった ため，15/10，20/15，25/20，30/25 抢よび 35/30 C 区では， それぞれ養液栽培を開始してから $31 ， 19,17,16$ 物よび 21 日後の同日に両品種を収穫した. $10 / 5^{\circ} \mathrm{C}$ 区では，両品 種ともに生育がきわめて緩慢であり，養液栽培開始から 45 日で栽培を打ち切った。 そのため, 両品種とも, $10 / 5^{\circ} \mathrm{C}$ 区の最大葉長は，収穫適期とされる $25 \mathrm{~cm}$ 程度よりかなり 短く，他の温度処理区よりも有意に短かった。一方，目視 により最大葉長が $25 \mathrm{~cm}$ 程度に達したと判断した日に収穫 を行ったものの, $25 / 20$ 扎よび $30 / 25^{\circ} \mathrm{C}$ 区では生育が速かっ たため, 収穫がやや遅れ, “はる久小松菜、に打ける $25 / 20^{\circ} \mathrm{C}$ 区, “楽天”に扣沙 $30 / 25^{\circ} \mathrm{C}$ 区の最大葉は，それ ぞれ $10 / 5$ および $35 / 30^{\circ} \mathrm{C}$ 区，10/5～20/15 ${ }^{\circ} \mathrm{C}$ 区より有意に 長かった. $10 / 5^{\circ} \mathrm{C}$ 区の葉数は，“はるみ小松菜”では 20/15 ${ }^{\circ} \mathrm{C}$ 区を除いた他の温度処理区と，“楽天’では $15 / 10$ 〜30/25 ${ }^{\circ} \mathrm{C}$ 区との間に有意な差はみられなかった。“はる み小松菜 に打ける $10 / 5^{\circ} \mathrm{C}$ 区の可食部新鮮重は, $15 / 10$ $25 / 20^{\circ} \mathrm{C}$ 区と有意な差はなく，30/25 $\mathrm{C}$ 区より大きかった. “楽天” に拈ける $10 / 5^{\circ} \mathrm{C}$ 区の可食部新鮮重は，他の温度処 理区と有意な差はなかった。両品種に颃ける $10 / 5^{\circ} \mathrm{C}$ 区の 可食部乾物重は， $15 / 10^{\circ} \mathrm{C}$ 区と有意な差はなく，他の温度 処理区よりも有意に大きかった。葉色は, 両品種ともに, 生育温度が低い処理区で濃くなる傾向が認められた。栽培 期間からみると, 両品種の最大葉の伸長成長は，25/20 お。 よび $30 / 25^{\circ} \mathrm{C}$ 区で速く，生育温度が低い $10 / 5^{\circ} \mathrm{C}$ 区で抑制 される傾向にあった。逆に，最大葉長に対する可食部新鮮 重は $10 / 5$ 打よび $15 / 10^{\circ} \mathrm{C}$ 区で大きかった。乾物率は，生 育温度が低い処理区で高い傾向であった。本研究では，食 用とされるコマッナの可食部の硝酸イオン濃度およびNR 活性に及ぼす生育温度の影響を検討することが目的であ 
第 1 表 コマツナ ‘はるみ小松菜”および“楽天’の栽培期間と収穫時の生育パラメーターに及ぼす生育温度の影響

\begin{tabular}{|c|c|c|c|c|c|c|c|c|c|}
\hline \multirow{2}{*}{ 品種 } & \multirow{2}{*}{ 生育温度 z } & \multirow{2}{*}{$\begin{array}{l}\text { 栽培期間 } \\
\text { (日) }\end{array}$} & \multirow{2}{*}{$\begin{array}{c}\text { 最大葉長 } \\
(\mathrm{cm})\end{array}$} & \multirow{2}{*}{$\begin{array}{l}\text { 葉数 } \\
\text { (枚) }\end{array}$} & \multirow{2}{*}{$\begin{array}{c}\text { 葉色 } \\
(\mathrm{SPAD})\end{array}$} & \multicolumn{2}{|c|}{ 可食部 } & \multirow{2}{*}{$\begin{array}{l}\text { 可食部新鮮重 (g) } \\
\text { /最大葉長 (cm) }\end{array}$} & \multirow{2}{*}{$\begin{array}{c}\text { 乾物率 } \\
(\%)\end{array}$} \\
\hline & & & & & & 新鮮重 $(\mathrm{g})$ & 乾物重（g） & & \\
\hline \multirow{6}{*}{$\begin{array}{l}\text { はるみ } \\
\text { 小松菜 }\end{array}$} & $10 / 5^{\circ} \mathrm{C}$ & 45 & $18.9 \mathrm{c}^{\mathrm{y}}$ & $7.9 \mathrm{a}$ & $68.2 \mathrm{a}$ & $23.7 \mathrm{ab}$ & $3.38 \mathrm{a}$ & $1.25 \mathrm{a}$ & $14.3 \mathrm{a}$ \\
\hline & $15 / 10^{\circ} \mathrm{C}$ & 31 & $25.3 \mathrm{ab}$ & $7.5 \mathrm{ab}$ & $52.4 \mathrm{~b}$ & $28.4 \mathrm{a}$ & $2.72 \mathrm{a}$ & $1.12 \mathrm{a}$ & $9.6 \mathrm{~b}$ \\
\hline & $20 / 15^{\circ} \mathrm{C}$ & 19 & $25.2 \mathrm{ab}$ & $7.1 \mathrm{~b}$ & $49.2 \mathrm{~b}$ & $18.9 \mathrm{bc}$ & $1.52 \mathrm{~b}$ & $0.75 \mathrm{bc}$ & $8.0 \mathrm{bc}$ \\
\hline & $25 / 20^{\circ} \mathrm{C}$ & 17 & $27.1 \mathrm{a}$ & $7.3 \mathrm{ab}$ & $41.0 \mathrm{c}$ & $21.2 \mathrm{~b}$ & $1.58 \mathrm{~b}$ & $0.78 \mathrm{~b}$ & $7.5 \mathrm{c}$ \\
\hline & $30 / 25^{\circ} \mathrm{C}$ & 16 & $26.8 \mathrm{ab}$ & $7.2 \mathrm{ab}$ & $40.8 \mathrm{c}$ & $14.7 \mathrm{c}$ & $1.22 \mathrm{~b}$ & $0.55 \mathrm{c}$ & $8.3 \mathrm{bc}$ \\
\hline & $35 / 30^{\circ} \mathrm{C}$ & 21 & $23.6 \mathrm{~b}$ & $7.8 \mathrm{ab}$ & $40.8 \mathrm{c}$ & $18.3 \mathrm{bc}$ & $1.77 \mathrm{~b}$ & $0.78 \mathrm{bc}$ & $9.7 \mathrm{~b}$ \\
\hline \multirow{6}{*}{ 楽天 } & $10 / 5^{\circ} \mathrm{C}$ & 45 & $21.1 \mathrm{c}$ & $6.8 \mathrm{~b}$ & $66.9 \mathrm{a}$ & $25.0 \mathrm{ab}$ & $3.00 \mathrm{a}$ & $1.18 \mathrm{a}$ & $12.0 \mathrm{a}$ \\
\hline & $15 / 10^{\circ} \mathrm{C}$ & 31 & $25.5 \mathrm{~b}$ & $7.6 \mathrm{~b}$ & $52.3 \mathrm{~b}$ & $31.0 \mathrm{a}$ & $2.85 \mathrm{a}$ & $1.22 \mathrm{a}$ & $9.2 \mathrm{~b}$ \\
\hline & $20 / 15^{\circ} \mathrm{C}$ & 19 & $26.1 \mathrm{~b}$ & $7.1 \mathrm{~b}$ & $46.7 \mathrm{c}$ & $23.2 \mathrm{~b}$ & $1.67 \mathrm{~b}$ & $0.89 \mathrm{~b}$ & $7.2 \mathrm{c}$ \\
\hline & $25 / 20^{\circ} \mathrm{C}$ & 17 & $26.7 \mathrm{ab}$ & $7.4 \mathrm{~b}$ & $40.9 \mathrm{~d}$ & $24.2 \mathrm{~b}$ & $1.54 \mathrm{~b}$ & $0.91 \mathrm{~b}$ & $6.4 \mathrm{c}$ \\
\hline & $30 / 25^{\circ} \mathrm{C}$ & 16 & $29.4 \mathrm{a}$ & $7.2 \mathrm{~b}$ & $38.6 \mathrm{~d}$ & $23.0 \mathrm{~b}$ & $1.54 \mathrm{~b}$ & $0.78 \mathrm{~b}$ & $6.7 \mathrm{c}$ \\
\hline & $35 / 30^{\circ} \mathrm{C}$ & 21 & $26.5 \mathrm{ab}$ & $9.9 \mathrm{a}$ & $39.3 \mathrm{~d}$ & $21.2 \mathrm{~b}$ & $1.65 \mathrm{~b}$ & $0.80 \mathrm{~b}$ & $7.8 \mathrm{c}$ \\
\hline
\end{tabular}

$\mathrm{z}$ 明期 /暗期温度 12 時間日長

y それぞれの品種に扔いて，異なるアルファベットはTukey の検定により 5\%水準で有意な差があることを示す

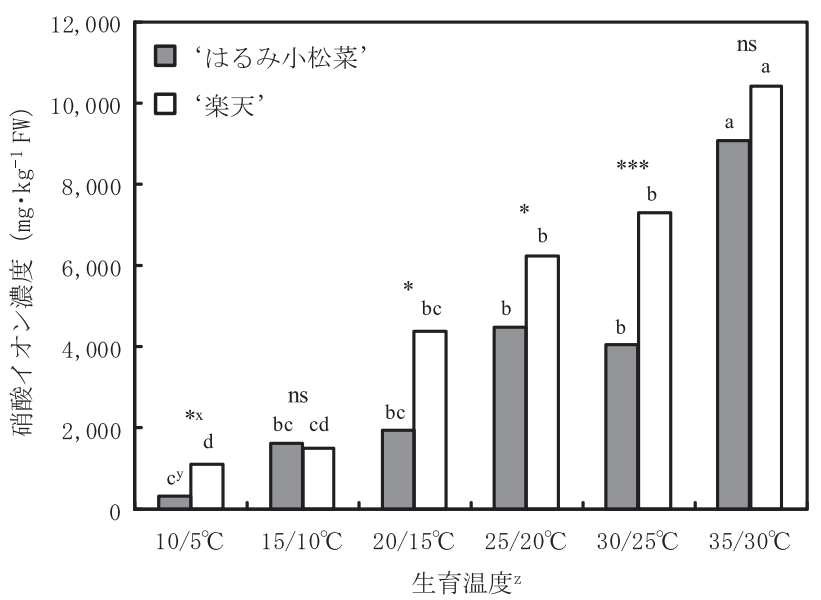

第 1 図 コマッナ ‘はるみ小松菜”拈よび ‘楽天”の硝酸イ オン濃度に及ぼす生育温度の影響

$\mathrm{z}$ 明期 $/$ 暗期温度 12 時間日長

y それぞれの品種に扣いて，異なるアルファベットは Tukeyの検定により 5\%水準で有意な差があることを 示す

x それぞれの生育温度に扮いて，***抢よび*は検定 により 0.1 および 5\%水準で有意な差があり；ns は有 意な差がないことを示す

り，10/5 抢よび $35 / 30^{\circ} \mathrm{C}$ 区でも極端に生育が抑制されるこ とはなく，硝酸イオン濃度およびNR活性測定のための試 料調製に問題はないと考えられた.

異なる温度条件下で生育させたコマツナ 2 品種の硝酸イ オン濃度を第 1 図に示した. 可食部全体の硝酸イオン濃度 は, ‘はる久小松菜”扎よび “楽天’ ともに, 生育温度が 高い処理区で高くなる傾向がみられた。 ‘はる久小松菜” の可食部全体の硝酸イオン濃度は, 最も低かった $10 / 5^{\circ} \mathrm{C}$ 区で $323 \mathrm{mg} \cdot \mathrm{kg}^{-1} \mathrm{FW}$, 最も高かった $35 / 30^{\circ} \mathrm{C}$ 区で $9,065 \mathrm{mg}$ $\mathrm{kg}^{-1} \mathrm{FW}$ であった。“楽天”の硝酸イオン濃度は, 最も低かっ た $10 / 5^{\circ} \mathrm{C}$ 区で $1,105 \mathrm{mg} \cdot \mathrm{kg}^{-1} \mathrm{FW}$, 最も高かった $35 / 30^{\circ} \mathrm{C}$ 区で $10,414 \mathrm{mg} \cdot \mathrm{kg}^{-1} \mathrm{FW}$ であった。葉菜類の硝酸イオン
濃度は高温期に高まる傾向にあることはよく知られてい る．寄藤ら（2005）は，国産野菜を対象として，全国規模 で市販野菜の硝酸イオン濃度を 3 年間にわたって調査した 結果，コマッナ，ハクサイおよびホウレンソウの硝酸イオ ン濃度は夏秋期に高い傾向があると報告している．藤原ら （2005）も，市販のホウレンソウの硝酸イオン濃度につい て調査し，その濃度は $1 \sim 3$ 月より 7〜9月に高まるとし ている. 本研究でも, 両品種ともに, 生育温度が高い処理 区で可食部全体の硝酸イオン濃度は高まる傾向がみられ, これらの報告と一致した.

コマツナの硝酸イオン濃度は, 日本食品標準成分表（文 部科学省科学技術・学術審議会資源調査分科会, 2010）に

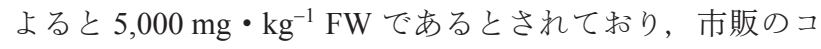
マッナ（試料数 197）で測定した結果では 4,060 mg・ $\mathrm{kg}^{-1}$ FWであると報告されている（寄藤ら，2005）。本研究に 扣いては, ‘はるみ小松菜”に打忊る $35 / 30^{\circ} \mathrm{C}$ 区 $(9,065 \mathrm{mg}$ $\left.\mathrm{kg}^{-1} \mathrm{FW}\right)$, “楽天” に打汀る $25 / 20^{\circ} \mathrm{C}$ 区 $\left(6,235 \mathrm{mg} \cdot \mathrm{kg}^{-1}\right.$ $\mathrm{FW}), 30 / 25^{\circ} \mathrm{C}$ 区 $\left(7,284 \mathrm{mg} \cdot \mathrm{kg}^{-1} \mathrm{FW}\right)$ および $35 / 30^{\circ} \mathrm{C}$ 区 $\left(10,424 \mathrm{mg} \cdot \mathrm{kg}^{-1} \mathrm{FW}\right)$ の硝酸イオン濃度は, 5,000 mg・ $\mathrm{kg}^{-1} \mathrm{FW}$ を超えた。全体的に, “楽天”の硝酸イオン濃度 は ‘はるみ小松菜”よりも高い傾向にあり，10/5, 20/15, $25 / 20$ 抢よび $30 / 25^{\circ} \mathrm{C}$ 区では有意な差が認められた。 コマ ツナの硝酸イオン濃度には品種間差のあることが報告され ており (貝塚, 2009), 筆者らの以前の研究（壇ら，2005） に扎いても, “楽天” の硝酸イオン濃度は ‘はるみ小松菜” より高かったことから，“楽天’は“はるみ小松菜”より も硝酸イオンを蓄積しやすい品種であると考えられた.

コマツナの硝酸イオン濃度は収穫時の土壌中の硝酸態窒 素濃度に影響され (中川ら，2000），コマッナやホウレン ソウでは培地中の窒素濃度が高い, あるいは生育時の光強 度が低いと硝酸イオン濃度が高まる（Cantliffe, 1972; Yazawa ら，1986）ことが報告されている. 本研究では，コマッナ の生育適温と考兄られる $25 / 20^{\circ} \mathrm{C}$ 区でも, “楽天’ の硝酸 
イオン濃度は $6,235 \mathrm{mg} ・ \mathrm{~kg}^{-1} \mathrm{FW}$ と高かった. 前述のように, “楽天”が硝酸イオンを蓄積しやすい品種であるとともに, 本研究での光強度 $(\mathrm{PPFD})$ が $300 \mu \mathrm{mol} \cdot \mathrm{m}^{-2} \cdot \mathrm{s}^{-1}$ であり, 自然光と比べて弱光条件であったことが，その一因であっ たと考光られた。一方, PPFD が $150 \mu \mathrm{mol} \cdot \mathrm{m}^{-2} \cdot \mathrm{s}^{-1}$ 程度 の弱光で夜間照明を行らと, 水耕ホウレンソウの硝酸イオ ン濃度を低減さ也る効果があることが報告されている（福 田ら，1999）。このことは，植物体に扮ける硝酸イオンの 蓄積には，光強度だけでなく，積算受光量も影響すること を示唆している. 本研究では, いずれの温度処理区でも一 定の光強度で栽培を行ったが，処理区によって栽培期間が 異なるため, 積算受光量が異なる. $20 / 15 \sim 35 / 30^{\circ} \mathrm{C}$ の生 育温度の処理区の間では， $35 / 30^{\circ} \mathrm{C}$ 区で，栽培日数が 21 日 と最も長く，積算受光量が最も多かったにも関わらず，“は るみ小松菜”扣よび “楽天” の可食部全体の硝酸イオン濃 度は最も高かった. 従って, いずれの品種でも硝酸イオン 濃度は, 積算受光量よりも生育温度の影響を強く受け, 高 温条件下で硝酸イオンの蓄積が促進されると考えられた。

異なる温度条件下で生育させたコマッナ 2 品種の NR 活 性を第 2 図に示した.NR は植物の硝酸同化の鍵酵素であ り，植物体中には活性型および非活性型の NR が存在して いると考光られている (Kaiser ら，1999). 非リン酸化 NR は活性型であり，活性型 NR がリン酸化され，14-3-3 タン パク質が結合すると不活性型になる。不活性型 NR が脱り ン酸化され，14-3-3 タンパク質がはずれると再び活性化さ れる（Kaiser・Huber, 2001）。活性型である非リン酸化 NR 活性は，“はるみ小松菜”では $10 / 5^{\circ} \mathrm{C}$ 区より $30 / 25$ 打よび $35 / 30^{\circ} \mathrm{C}$ 区で，“楽天”では $10 / 5^{\circ} \mathrm{C}$ 区より $20 / 15 \sim 35 / 30^{\circ} \mathrm{C}$ 区で有意に低かった，不活性型である，リン酸化された NR を含む全 NR 活性は，“はるみ小松菜”では $20 / 15^{\circ} \mathrm{C}$ 区 より $35 / 30^{\circ} \mathrm{C}$ 区で，“楽天’では $10 / 5^{\circ} \mathrm{C}$ 区より $30 / 25$ 打よ び $35 / 30^{\circ} \mathrm{C}$ 区で有意に低かった。“楽天” の非リン酸化 NR 活性は $20 / 15$ 扤よび $25 / 20^{\circ} \mathrm{C}$ 区で，全 NR 活性は $20 / 15^{\circ} \mathrm{C}$ 区で ‘汶小松菜”より有意に低かった，概して，両品 種の非リン酸化抒よび全 NR 活性は, 高い生育温度条件下 で低くなる傾向がみられた，植物体の NR 活性には，光強 度や培地中の硝酸イオン濃度が顕著な影響を及ぼすことは よく知られている (Hageman・Flesher, 1960; Redinbaugh・ Campbell, 1991). 特に, 光に対する NR の反応はきわめて 速く, 植物を暗条件下に置くと NR 活性は直ちに低下し, 明条件下に戻すと直ちに回復する (Kojima ら, 1995). 一方, NR 活性に及ぼす温度の影響について検討した例は少ない が，バレイショの葉の NR 活性は, 高温条件下で低く, 低 温条件下で高くなることが報告されている（Ghoshら， 2000)。本研究でも, コマッナ 2 品種の NR 活性は, 生育 温度の高い処理区で低くなる傾向がみられ, 光に対する反 応ほど顕著ではないものの，生育温度の影響を受けるもの と考党られた。

野菜の多くは，好硝酸性植物であり，硝酸イオンの形で
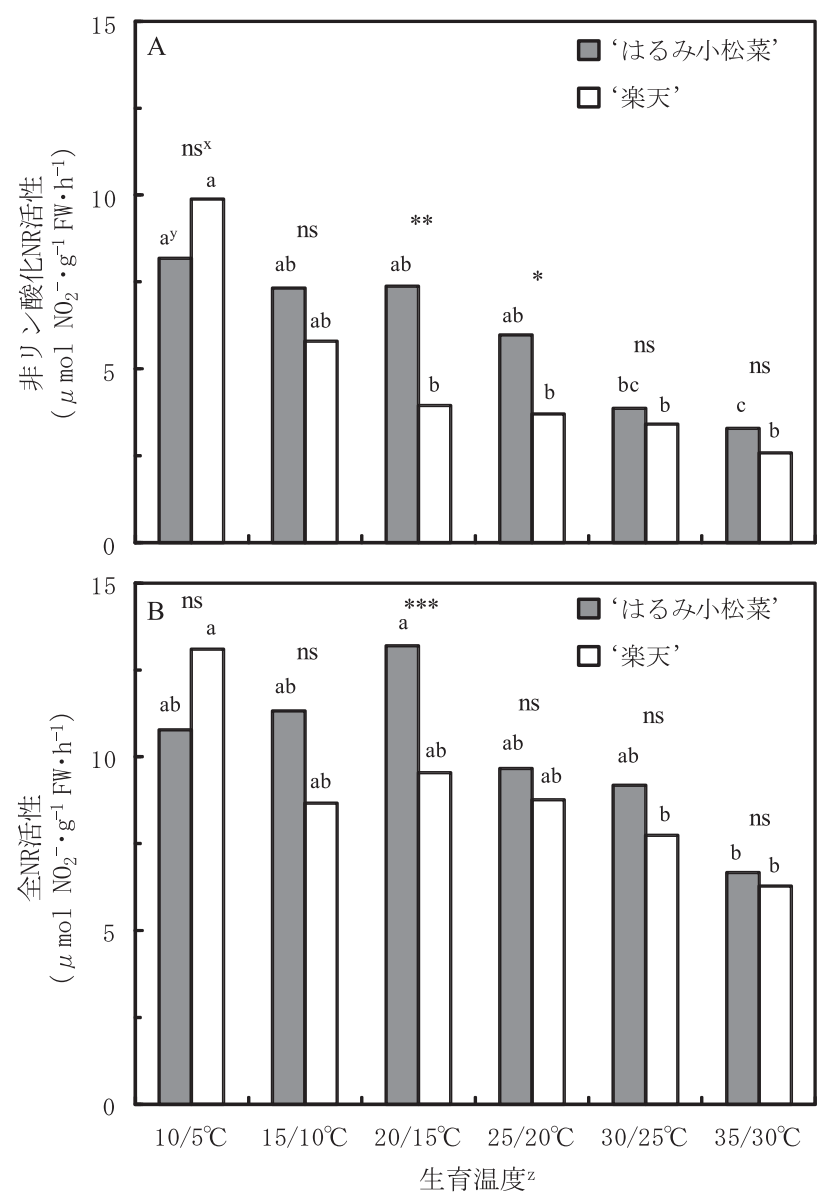

第 2 図コマッナ ‘はるみ小松菜”物よび ‘楽天’ の非リン 酸化硝酸還元酵素 (NR) 活性 (A) 打よび全 NR 活性 (B) に及ぼす生育温度の影響

$\mathrm{z}$ 明期 / 暗期温度 12 時間日長

y それぞれの品種に打いて，異なるアルファベットは Tukeyの検定により $5 \%$ 水準で有意な差があることを 示す

$\mathrm{x}$ それぞれの生育温度に拈いて，***，**扎よび*は $\mathrm{t}$ 検定により $0.1 ， 1$ 打よび $5 \%$ 水準で有意な差があり； ns は有意な差がないことを示す

大部分の窒素を吸収する。硝酸イオンとして吸収された窒 素は, アミノ酸に還元・同化されて, はじめて植物に利用 される，植物体内で還元されるよりも多くの硝酸イオンが 吸収されると未還元の硝酸イオンとして植物体内に蓄積す る. 硝酸イオンのアミノ酸への還元・同化の第一段階は硝 酸イオンから亜硝酸イオンへの還元反応であり，NR はこ の反応を触媒している，そのため，NRの反応速度が硝酸 同化系の速度を決定していると考光られている（白石・中 川，2000）。“はる久小松菜”打よび“楽天’ともに活性型 である非リン酸化 NR 活性と可食部全体の硝酸イオン濃度 との間に，“はる久小松菜’ では全 NR 活性と可食部全体 の硝酸イオン濃度との間に有意な負の相関関係がみられた (第 3 図)。“楽天”に扔いても，全 NR 活性が比較的低い にも関わらず，硝酸イオン濃度が低かった $15 / 10^{\circ} \mathrm{C}$ 区の結 果を除くと，全 NR 活性と硝酸イオン濃度との間には有意 


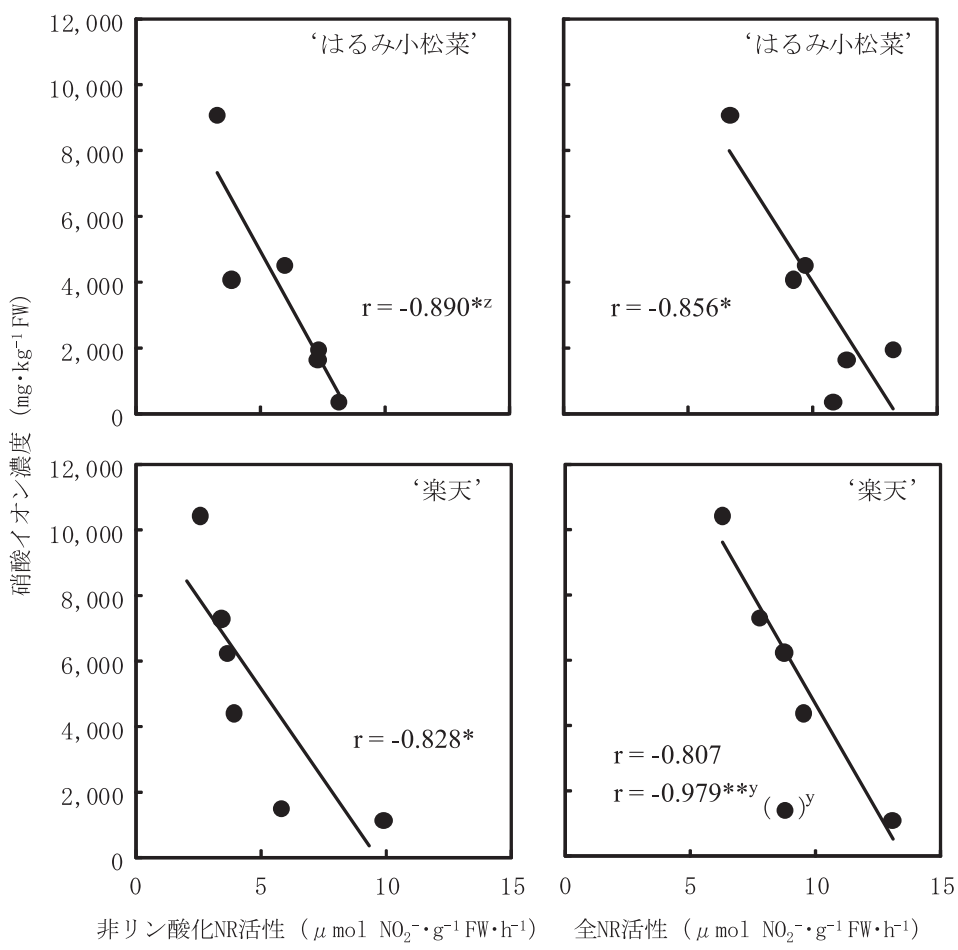

第 3 図コマツナ“はるみ小松菜”扣よび“楽天’の非りン酸化硝酸還元酵素（NR）活性扣よび全 NR 活性と硝酸イオン濃度 との関係

z*抢よび**はt 検定によりそれぞれ 5 抒よび $1 \%$ 水準で有意であることを示す

y 全 NR 活性が比較的低いにも関わらず，硝酸イオン濃度が低かった

$15 / 10^{\circ} \mathrm{C}$ 区の結果を除いて計算した相関係数

な負の相関関係が認められた. 畑ら（1979）は，貯蔵中に カボチャの硝酸イオン濃度は著しく低下し, NR 活性が上 昇することを観察し, 硝酸イオンの挙動はNR 活性と密接 な関連があると指摘している. 本研究に拈いて, 高温条件 下で生育させたユマツナの硝酸イオン濃度が高かったの は，NR 活性の低下によると考えられる.

以上のことから，コマッナの硝酸イオン濃度と NR 活性 の間には負の相関関係が認められ，高温下で栽培したコマ ツナではNR 活性が低下寸るために, 硝酸イオン濃度が高 くなると考觉られた。 このよらに，コマッナなどの葉菜類 を高温期に栽培すると硝酸イオン濃度が上昇しやすいと考 えられる. 高温期の栽培で葉菜類の硝酸イオン濃度の上昇 を抑えるためには，適正な施肥管理を行らことが前提とな る. これまでに, コマッナの硝酸イオン濃度には品種間差 のあることが報告されて抢り（貝塚，2009），高温期には 硝酸イオン濃度が上昇しにくい品種を栽培することが望ま しい. 本研究では, ‘はるみ小松菜”报よび “楽天”の 2 品種のみで検討を行ったが，コマッナには数多くの品種が あり, 今後, 本研究で供試した 2 品種も含めて, さらに多 くの品種に执いて硝酸イオン濃度を調査し, 高温期でも硝 酸イオン濃度が低い品種を選定する必要がある。一方, 高 温期にコマッナを栽培すると，葉色が薄くなり，徒長し， 葉柄が細長くなって折損しやすいなど, 商品性が低下寸る ことが問題とされて扣り，高温期に商品性が低下しにくい $\mathrm{F}_{1}$ 品種が育成されている(飛騨，2001）。本研究では， 2
品種ともに生育温度が高い処理区で葉色が薄く, 最大葉長 に対する新鮮重，ならびに乾物率が低下する傾向がみられ た（第 1 表）そそのため，高温期でも硝酸イオン濃度が低 いコマツナの品種を選定する際には，高温による形状など への影響，すなわち商品性の低下についても考慮する必要 がある、また，高温期の葉菜類の栽培では，昇温抑制を目 的として遮光が行われることが多い. 前報で, 著者らは, 光強度が高まると養液栽培でのコマッナの硝酸イオン濃度 が低下し，非リン酸化 NR 活性が高まることを示した（壇 ら，2005). 逆に，遮光によってコマッナの硝酸イオン濃 度が高まることが報告されている（Yazawa ら，1986）こ とから, 光強度が低下すると硝酸イオン濃度は高くなると 予想される，遮光により気温际よび植物体の葉温は低下す るが，光強度も低下する，そのため，NR活性および硝酸 イオン濃度に及ぼす温度と光強度の相互作用を明らかにす ることは, 高温期の葉菜類での硝酸イオン濃度を低減させ る栽培技術を開発するらえで重要であると考えられる。

\section{摘 要}

コマッナ（Brassica rapa L. var. perviridis）の硝酸イオン 濃度拈よび硝酸還元酵素（NR）活性に及ぼす生育温度の 影響について検討するために, “はる久小松菜”扣よび“楽 天’を用いて，生育温度 $10 / 5 ， 15 / 10 ， 20 / 15 ， 25 / 20 ， 30 / 25$ および $35 / 30^{\circ} \mathrm{C}, 12$ 時間日長, $\operatorname{PPFD} 300 \mu \mathrm{mol} \cdot \mathrm{m}^{-2} \cdot \mathrm{s}^{-1}$ の 環境条件で養液栽培を行った。全体的に, “はるみ小松菜” 
より “楽天’ で可食部の硝酸イオン濃度は高かった. 両品 種ともに, 生育温度が高いと, 硝酸イオン濃度が高く, 非 リン酸化および全 NR 活性は低くなる傾向がみられた. 非 リン酸化および全 NR 活性と硝酸イオン濃度との間には負 の相関関係が認められ，高温条件下ではNR 活性が低くな ることにより硝酸イオン濃度が高くなると考学られた.

謝 辞 本研究を行うにあたり, 神戸大学大学院自然科 学研究科の王子善清前教授, 白石斉聖博士より硝酸還元酵 素活性の測定法を御指導頂いた。 ここに記して深謝の意を 表します.

\section{引用文献}

Cantliffe, D. J. 1972. Nitrate accumulation in spinach grown under different light intensities. J. Amer. Soc. Hort. Sci. 97: $152-154$.

壇 和弘・大和陽一 ・ 今田成雄. 2005. 光強度および赤色 光 / 遠赤色光比の違いがコマツナの硝酸イオン濃度お よび硝酸還元酵素活性に及ぼす影響. 園学研. 4: 323328.

藤原隆広 - 熊倉裕史 - 大田智美 - 吉田祐子 - 亀野 貞. 2005. 市販ホウレンソウのL-アスコルビン酸扣よび 硝酸塩含量の周年変動. 園学研. 4: 347-352.

福田直也・宮城 慎・鈴木洋二・池田英男・高柳謙治. 1999. 深夜照明と培養液からの $\mathrm{NO}_{3}{ }^{-}$除去が水耕ホウ レンソウの生育と葉の汁液中 $\mathrm{NO}_{3}{ }^{-}$濃度に及ぼす影響. 園学雑. 68: 146-151.

Ghosh, S. C., K. Asanuma, A. Kusutani and M. Toyota. 2000. Effect of temperature at different growth stage on nonstructural carbohydrate, nitrate reductase activity and yield of potato. Environ. Control Biol. 38: 197-206.

Hageman, R. H. and D. Flesher. 1960. Nitrate reductase activity in corn seedlings as affected by light and nitrate content of nutrient media. Plant Physiol. 35: 700-708.

畑 明美 - 茶珍和雄 - 緒方邦安. 1979. 野菜の貯蔵中の硝 酸塩含量の消長と生体内の代謝活性との関係. 食科工 誌. 26: 180-188.

飛騨健一. 2001. ツケナ. p. 862-877. 西 貞夫監修. 新編 野菜園芸ハンドブック。養賢堂. 東京.

Kaiser, W. M. and S. C. Huber. 2001. Post-translational regulation of nitrate reductase: mechanism, physiological relevance and environmental triggers. J. Exp. Bot. 52: 19811989.

Kaiser, W. M., H. Weiner and S. C. Huber. 1999. Nitrate reductase in higher plants: a case study for transduction of environmental stimuli into control of catalytic activity. Physiol. Plantarum 105: 385-390.
貝塚隆史. 2009. コマッナ (Brassica campestris L.) の植物 体内に打ける硝酸態窒素の集積と低減に関する研究. 茨城農総七園研報. 3:1-53.

加藤一幾・植田稔宏・松本英一. 2013. コマッナの八ウス 周年栽培に打的窒素施肥量と可食部硝酸イオン濃度 の低減を目的とした窒素診断施肥. 園学研. 12: 43-49.

Kojima, M., S. J. Wu, H. Fukui, T. Sugimoto, T. Nanmori and Y. Oji. 1995. Phosphorylation/dephosphorylation of komatsuna (Brassica campestris) leaf nitrate reductase in vivo and in vitro in response to environmental light conditions: Effects of protein kinase and protein phosphatase inhibitors. Physiol. Plantarum 93: 139-145.

文部科学省科学技術 - 学術審議会資源調査分科会. 2010 . 日本食品標準成分表. p. 80-81. 全国官報販売協同組合. 東京.

中川祥治・山本秀治・五十嵐勇紀・田村夕利子・吉田企世 子. 2000. 堆肥および有機質肥料の施用がコマッナ (Brassica campestris L. rapifera group) の硝酸, 糖，ア スコルビン酸拈よび $\beta$-カロチン含量に及ぼす影響. 土肥誌. 71: 625-634.

Redinbaugh, M. G. and W. H. Campbell. 1991. Higher plant responses to environmental nitrate. Physiol. Plantarum 82: 640-650.

白石斉聖 - 中川弘毅. 2000. 硝酸還元酵素の機能と構造. 化学と生物. 38: 270-277.

Sohar, J. and J. Domoki. 1980. Nitrite and nitrate in human nutrition. Bibithca Nutr. Dieta. 29: 65-74.

孫 尚穆・米山忠克. 1996. 野菜の硝酸 : 作物体の硝酸の 生理，集積，人の摂取. 農業拈よび園芸. 71: 11791182.

建部雅子・佐藤信仁・石井か扣る・米山忠克. 1996. 緩効 性窒素肥料の施用がホウレンソウのシュウ酸, アスコ ルビン酸, 糖, 硝酸含有率に与える影響. 土肥誌. 67: $147-154$.

建部雅子・米山忠克. 1995. 作物栄養診断のための小型反 射式光度計システムによる硝酸执よび還元型アスコル ビン酸の簡易測定法. 土肥誌. 66: 155-158.

Yazawa, S., H. Tanaka and T. Namiki. 1986. Nitrate accumulation in Chinese mustard (Brassica campestris cv. Marubakomatsuna) grown under different light conditions. Sci. Rep. Kyoto Pref. Univ. Agr. 38: 1-6.

寄藤俊明・新畑雅企・山村香織・大津知子 - 井口 潤 - 平 松絹子・鈴木千恵・生本俊明・宮武 信・佐藤耕一・ 西山武夫・鈴木忠直. 2005. 市販の国産野菜に含まれ ている硝酸濃度の実態調査. 食科工誌. 52: 605-609. 